\title{
INFLUENCE OF WARM ROLLING AND HEAT TREATMENT IN THE ALPHA-GAMMA AREA OF A THREE-LAYER STRIP ON THE APPEARANCE OF EARS DURING CUP DEEP DRAWING
}

\author{
VPLIV TOPLEGA VALJANJA IN TOPLOTNE OBDELAVE V \\ AUSTENITNO-FERITNEM PODROČJU TROSLOJNEGA TRAKU NA \\ POJAV UŠES MED GLOBOKIM VLEKOM SKODELIC
}

\author{
Omer Beganović, Mustafa Hadžalić, Suvad Kesić \\ University of Zenica, Institute "Kemal Kapetanović" in Zenica, Travnička cesta 7, Bosnia and Herzegovina \\ Prejem rokopisa - received: 2018-06-29; sprejem za objavo - accepted for publication: 2018-11-22
}

doi:10.17222/mit.2018.131

\begin{abstract}
Eearing is the most common defect that may occur during cup deep drawing. A removal of excess material from drawn parts causes a wastage of the material. Therefore, it is necessary to minimize earing as much as possible. A negative effect of warm rolling and annealing in the alpha-gamma area on the earing in the case of an explosive-welded three-layer strip consisting of CuZn10 clad layers and the central DC04 steel layer is described in this article. Warm rolling of all samples started in the alpha-gamma area $\left(850^{\circ} \mathrm{C}\right)$ of the steel layer. Some of them were reheated to the same temperature after each pass while others were not reheated after the last three passes. In both cases, ears appeared. The final annealing was carried out at temperatures between $700-930{ }^{\circ} \mathrm{C}$. Regardless of the thermomechanical history of the samples, the final annealing in the alpha-gamma area $(750,800$ and 850$){ }^{\circ} \mathrm{C}$ caused earing, even in the case of a sample exposed to a higher degree of cold deformation, including intermediate recrystalization annealing at $700{ }^{\circ} \mathrm{C}$, which, after the final annealing at $700{ }^{\circ} \mathrm{C}$, does not have the tendency to create ears. Because of this negative effect, annealing and prolonged warm rolling in the alpha-gamma area should be avoided.

Key words: three-layer strip, anisotropy, deep drawing, earing
\end{abstract}

Nastajanje ušes je najbolj pogosta napaka, ki se pojavlja med globokim vlekom skodelic. Odstranjevanje odvečnega materiala z globoko vlečenih delov predstavlja odpadni material. Zato je potrebno nastajanje ušes zmanjšati na najmanjšo možno mero. Avtorji opisujejo negativen vpliv toplega valjanja in žarjenja $v$ feritno-austenitnem področju (alfa-gama) na nastanek ušes med medsebojnim eksplozivnim varjenjem treh slojev (plasti) sestavljenih iz dveh zunanjih plasti CuZn10 in sredinsko plastjo DC04 jekla. Toplo valjanje vseh vzorcev se je začelo z valjanjem jekla v afa-gama področju $\left(850{ }^{\circ} \mathrm{C}\right)$. Nekaj vzorcev je bilo vsakokrat ponovno ogretih na dano temperaturo pred vsakim prehodom skozi valje, nekaj vzorcev pa niso ponovno ogrevali med zadnjimi tremi prehodi. V vseh primerih so se pojavljale valjarske napake (ušesa). Končno žarjenje so izvali pri temperaturah med 700 in $930^{\circ} \mathrm{C}$. Ne glede na termo-mehansko zgodovino vzorcev in končno žarjenje (pri $750{ }^{\circ} \mathrm{C}, 800{ }^{\circ} \mathrm{C}$ in $850^{\circ} \mathrm{C}$ ) so se vedno pojavljala ušesa, celo v primeru vzorcev z višjim deležem hladne deformacije z vključenim vmesnim rekristalizacijskim žarjenjem pri $700{ }^{\circ} \mathrm{C}$, ki po zaključnem žarjenju na $700{ }^{\circ} \mathrm{C}$ ni kazalo tendence pojava ušes. Zaradi tega negativnega efekta žarjenja se je potrebno izogibati dolgotrajnega toplega valjanja v alfa-gama področju.

Ključne besede: trislojni trak, anizotropija, globoki vlek, nastajanje ušes

\section{INTRODUCTION}

Deep drawing is a manufacturing process for changing flat sheets/strips into geometrical cup-shaped metal products without a failure or excessive localized thinning. ${ }^{1-2}$ In this process, a sheet/strip metal blank is radially drawn into a forming die with the mechanical movement of the punch to form a cup. ${ }^{3}$ The most common defect that may occur during cup deep drawing is the earing. The earing is the appearance of waviness (ears) on the upper edges of a deep-drawn cup. The formation of ears results in unequal metal flows in different directions due to the anisotropy of the metal sheet/strip. The earing is not desirable as additional processing is required to trim the excess metal, causing a wastage of the material. ${ }^{4}$ Therefore, it is necessary to

*Corresponding author e-mail: omer.beganovic@miz.unze.ba minimize the earing as much as possible. The purpose of this paper is to describe the influence of warm rolling and heat treatment in the alpha-gamma area of the earing in the case of explosive-welded three-layer strip consisting of CuZn10 clad layers and the central DC04 steel layer.

The explosion-welding process is primarily used for cladding certain metals with other metals with a better corrosion resistance as in the case of cladding lowcarbon steel with copper alloys. Explosion welding is a solid-state welding process that can be used for joining metallurgically compatible metals but also metallurgically non-compatible metals that cannot be joined with any other welding technique. A weld surface with a metallurgical bond between the joined materials is produced due to a controlled detonation of a chemical explosive ${ }^{5}$ that is placed on the cladding metal (flyer plate). The pressure created by the explosive detonation directs the flyer plate to the fixed base-metal plate, 
making them to collide and bond at their interface. ${ }^{6}$ Because of the high pressure produced by the explosive detonation, the metals at the interface are locally plastically deformed and metallurgically bonded. Since the bonded metals have different mechanical and physical properties, they behave differently during the plastic deformation. Since the melting temperature of alloy CuZn10 is significantly lower (a melting range of $\left.1025-1045^{\circ} \mathrm{C}\right)^{7-8}$ than the melting temperature of steel DC04 (a melting range of $1400-1500{ }^{\circ} \mathrm{C}$ ), the hotworking temperature range of the $\mathrm{CuZn} 10$ alloy $\left(750-900{ }^{\circ} \mathrm{C}\right)^{7-8}$ is significantly lower than the normal hot-working temperature range of the DC04 steel. Because of that, the rolling of the steel (the central layer of the three-layer strip) should be done in the alphagamma and ferrite-pearlite area. This allows a different microstructure compared to the cases when the rolling process is performed in the gamma area.

Regardless of the thermomechanical conditions of warm rolling, the microstructures of the rolled strips are similar to each other after warm rolling and after recrystallization annealing. ${ }^{9}$ Thermomechanical cycles include heating in the alpha-gamma or ferrite-pearlite temperature range, rolling, reheating, in different manners, to the rolling temperature and repeated rolling causing fragmentation $^{10-11}$ of cementite lamellae and their partial spheroidisation inside the pearlite areas. ${ }^{12-13}$ Therefore, the recrystallization annealing for the elimination of strain effects is also soft annealing because of a complete spheroidisation of the cementite in the ferrite matrix. ${ }^{9}$ The subsequent cold rolling of the strips with such microstructures, in combination with the final recrystallization annealing, gives similar microstructures (spheroidized cementite in the ferrite matrix). Unlike the case, in which recrystallization annealing produces a strong recrystallization texture after a very heavy cold deformation, there are several cases, in which nearly random textures are produced after only a small cold deformation. ${ }^{14}$ The development of a recrystallization texture indicates the appearance of the preferred orientation, anisotropy of the mechanical properties and thus the increased earing sensitivity.

\section{EXPERIMENTAL PART}

\subsection{Materials}

The sample for rolling was a three-layer plate obtained with explosive welding. Plates of a copper alloy (CuZn10 according to the standard EN 1652) were applied to the plate of low-carbon steel (DC04 steel for deep drawing according to the standard EN 10130) on both sides (the top and bottom side). The chemical compositions of particular layers are presented in Table $\mathbf{1 .}$ The dimensions of the three-layer plate obtained with explosive welding were $(35 \times 1200 \times 2000) \mathrm{mm}$. Strips with a nominal width of $90 \mathrm{~mm}$ were cut with a water jet from the three-layer plate.

\subsection{Experiments}

Warm rolling of the three-layer strips was performed on light-section rolling mill SKET with $\phi 370 \mathrm{~mm}$ from $35 \mathrm{~mm}$ to $4.3 \mathrm{~mm}$ in thickness ( 8 passes), and a laboratory light-section rolling mill with $\phi 250 \mathrm{~mm}$ from $4.3 \mathrm{~mm}$ to $2.3 \mathrm{~mm}$ in thickness ( 3 passes). Cold rolling of the three-layer strips was performed on cold rolling mill LOMA from $4.3 \mathrm{~mm}$ or $2.3 \mathrm{~mm}$ to $1.33 \mathrm{~mm}$ in thickness (Table 2).

After warm rolling and recrystallization annealing $\left(700{ }^{\circ} \mathrm{C} / 1 \mathrm{~h}\right)$, and before cold rolling, an oxide film was removed from the strip surface with a $7.5 \%$ sulphuric acid heated to a temperature of $35-40{ }^{\circ} \mathrm{C}$. The holding time of the strip in the sulphuric acid was 8 min. After the final heat treatments, the newly formed oxide film was removed in the same way as after the warm rolling. The microstructure of all the samples with a thickness of $2.3 \mathrm{~mm}$, consisting of ferrite with completely spheroidized cementite was a common microstructure obtained after the described thermomechanical treatments. ${ }^{9}$ The thickness of individual layers was 0.098 and $0.094 \mathrm{~mm}$ in the case of CuZn10 clad layers and $1.138 \mathrm{~mm}$ in the case of the central steel layer, so the ratio of the total thickness of the CuZn10 layers and the total thickness of the three-layer strip was $14.4 \% .{ }^{15}$ Consequently, the behaviour of the three-layer strip was mainly determined by the behaviour of the central steel layer. The final width of the strips after warm and cold rolling was 102 $\mathrm{mm}$ and after the longitudinal slitting of the side edges of the strip by circular knives, it was $84 \mathrm{~mm}$. The final heat treatments were carried out with the aim that the grain size of all the strips (samples) should be between G 6.0 and G 8.0. Skin-pass rolling as the last step of the strip processing was performed on cold-rolling mill LOMA with an approximately $2 \%$ reduction in thickness.

NOTE: Annealing at $700{ }^{\circ} \mathrm{C}$ is a recrystallization process consisting of heating $(1 \mathrm{~min} / \mathrm{mm})$ and holding the samples $(1 \mathrm{~h})$ at that temperature. Heat treatments at other (higher) temperatures consist of heating $(1 \mathrm{~min} / \mathrm{mm})$ and holding the samples (18 $\mathrm{min})$ at these temperatures. Strips were in coils with dimensions of $\phi 200 / \phi 235 \mathrm{~mm}$ and a weight of up to $8 \mathrm{~kg}$.

Table 1: Chemical compositions of steel DC04 and CuZn10 alloy layers

\begin{tabular}{|c|c|c|c|c|c|c|c|c|c|c|c|}
\hline \multirow{2}{*}{ Material } & \multicolumn{10}{|c|}{ Content of elements in mass fractions (w/\%) } \\
\cline { 2 - 23 } & $\mathrm{C}$ & $\mathrm{Mn}$ & $\mathrm{Si}$ & $\mathrm{P}$ & $\mathrm{S}$ & $\mathrm{Al}$ & $\mathrm{N}$ & $\mathrm{Cu}$ & $\mathrm{Zn}$ & $\mathrm{Pb}$ & $\mathrm{Fe}$ \\
\hline DC04 & 0.08 & 0.30 & 0.03 & 0.009 & 0.003 & 0.023 & 0.005 & - & - & $\mathrm{Rem}$. \\
\hline CuZn10 & - & - & - & - & - & - & & 89.9 & 10.1 & $<0.01$ & $<0.01$ \\
\hline
\end{tabular}


O. BEGANOVIĆ et al.: INFLUENCE OF WARM ROLLING AND HEAT TREATMENT IN THE ALPHA-GAMMA AREA ..

Table 2: Basic parameters of warm and cold rolling and the final heat treatments of different strips/samples

\begin{tabular}{|c|c|c|c|c|c|}
\hline \multirow{2}{*}{$\begin{array}{l}\text { Strip/ } \\
\text { sample }\end{array}$} & \multicolumn{2}{|l|}{ Warm rolling } & \multicolumn{2}{|l|}{ Cold rolling } & \multirow{2}{*}{$\begin{array}{l}\text { Temperature of } \\
\text { the final heat } \\
\text { treatment }\end{array}$} \\
\hline & Process content & $\begin{array}{c}\text { Height } \\
\text { reduction }(\%)\end{array}$ & Process content & $\begin{array}{c}\text { Height } \\
\text { reduction }(\%)\end{array}$ & \\
\hline S 1.1 & \multirow{2}{*}{$\begin{array}{l}\text { Heating to } 850{ }^{\circ} \mathrm{C} \text {; rolling: } 34.8 \mathrm{~mm} \\
\rightarrow 4.3 \mathrm{~mm} \text { with reheating to } 850{ }^{\circ} \mathrm{C} \\
\text { after each pass }\end{array}$} & \multirow[b]{2}{*}{87.7} & \multirow{2}{*}{$\begin{array}{l}\text { Annealing: } 700{ }^{\circ} \mathrm{C} \text {; rolling: } \\
4.3 \mathrm{~mm} \rightarrow 2.3 \mathrm{~mm} \text {; } \\
\text { annealing: } 700^{\circ} \text {; rolling: } 2.3 \\
\mathrm{~mm} \rightarrow 1.33 \mathrm{~mm}\end{array}$} & \multirow[b]{2}{*}{69.1} & $700{ }^{\circ} \mathrm{C}$ \\
\hline S 1.2 & & & & & $800{ }^{\circ} \mathrm{C}$ \\
\hline S 2 & $\begin{array}{l}\text { Heating to } 850{ }^{\circ} \mathrm{C} \text {; rolling: } 34.8 \mathrm{~mm} \\
\rightarrow 2.3 \mathrm{~mm} \text { with reheating to } 850^{\circ} \mathrm{C} \\
\text { after each pass }\end{array}$ & 93.4 & $\begin{array}{l}\text { Annealing: } 700{ }^{\circ} \mathrm{C} \text {; rolling: } \\
2.3 \mathrm{~mm} \rightarrow 1.33 \mathrm{~mm}\end{array}$ & 42.2 & $700{ }^{\circ} \mathrm{C}$ \\
\hline S 3.1 & \multirow{5}{*}{$\begin{array}{l}\text { Heating to } 8500^{\circ} \mathrm{C} \text {; rolling: } 34.8 \mathrm{~mm} \\
\rightarrow 4.3 \mathrm{~mm} \text { with reheating to } 850^{\circ} \mathrm{C} \\
\text { after each pass; rolling: } 4.3 \mathrm{~mm} \rightarrow \\
2.3 \mathrm{~mm} \text { without reheating between the } \\
\text { passes }\end{array}$} & \multirow{5}{*}{93.4} & \multirow{5}{*}{$\begin{array}{l}\text { Annealing: } 700{ }^{\circ} \mathrm{C} \text {; rolling: } \\
2.3 \mathrm{~mm} \rightarrow 1.33 \mathrm{~mm}\end{array}$} & \multirow{5}{*}{42.2} & $700^{\circ} \mathrm{C}$ \\
\hline S 3.2 & & & & & $750{ }^{\circ} \mathrm{C}$ \\
\hline S 3.3 & & & & & $800^{\circ} \mathrm{C}$ \\
\hline S 3.4 & & & & & $850^{\circ} \mathrm{C}$ \\
\hline S 3.5 & & & & & $930^{\circ} \mathrm{C}$ \\
\hline
\end{tabular}

Table 3: Tensile properties of the samples (strips) and the corresponding grain size

\begin{tabular}{|l|c|c|c|c|c|c|c|c|}
\hline \multicolumn{1}{|c|}{ Sample (strip) } & S1.1 & S 1.2 & S 2 & S 3.1 & S 3.2 & S 3.3 & S 3.4 & S 3.5 \\
\hline Yield strength, $R_{\mathrm{p} 0,2}(\mathrm{MPa})$ & 208 & 234 & 200 & 231 & 238 & 232 & 219 & 215 \\
\hline Tensile strength, $R_{\mathrm{m}}(\mathrm{MPa})$ & 315 & 340 & 327 & 349 & 323 & 354 & 331 & 346 \\
\hline Elongation, $A(\%)$ & 32.0 & 29.5 & 29.0 & 31.0 & 27.5 & 27.5 & 27.0 & 32.0 \\
\hline Grain size no, $G$ & 6.5 & 6.5 & 6.5 & 6.5 & 7.0 & 6.5 & 6.5 & 7.5 \\
\hline
\end{tabular}
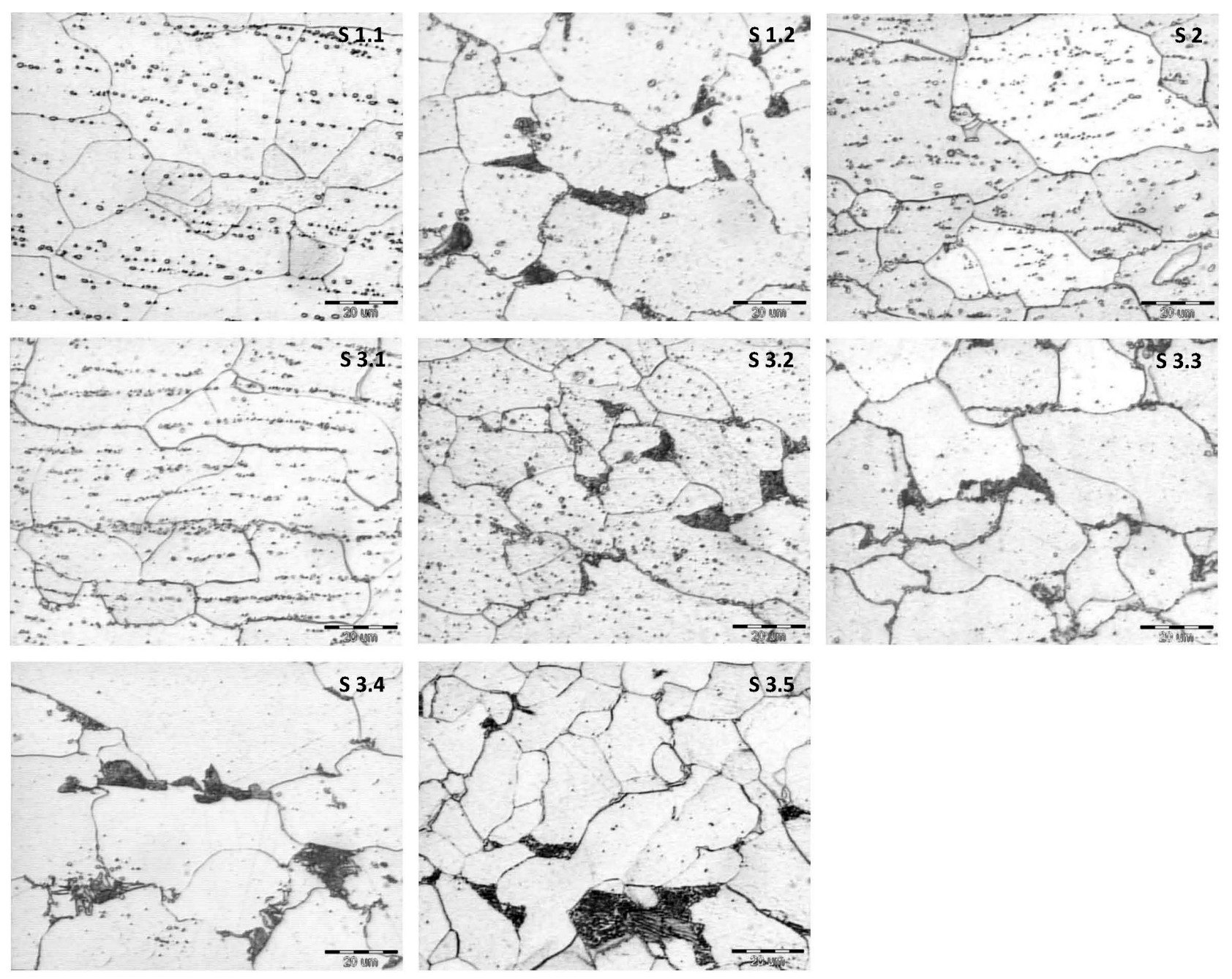

Figure 1: Microstructures of the steel-layer samples after rolling and final heat treatment $\left(2 \% \mathrm{HNO}_{3}\right)$ 

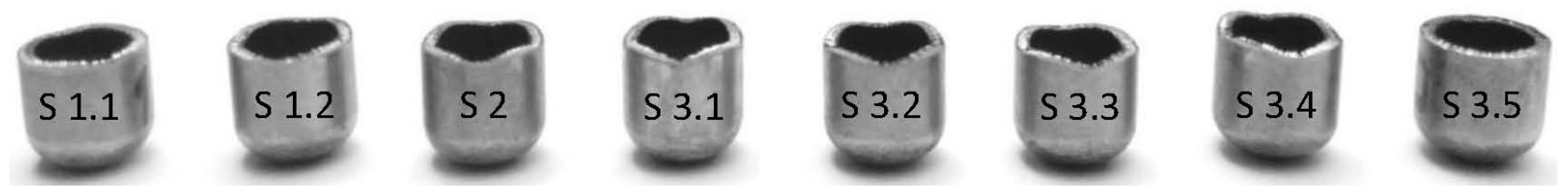

Figure 2: Deep-drawn cups

\section{RESULTS AND DISCUSSION}

The tensile tasting of all the obtained strips was performed according to standard BAS EN ISO 6892-1:2017. The average grain size was determined according to standard ASTM E112-13. The results of the tensile testing and the corresponding grain size are presented in Table 3.

The achieved values of the tensile properties are common for a three-layer strip of this type after skinpass rolling. The applied heat-treatment parameters, the heating time and holding time (Table 2), provided a grain size between G 6.5 and G 7.5 for the steel layer of all rolled samples (strips). The microstructures of the steel layers of all the samples (strips) are presented in Figure 1. Depending on the final heat-treatment temperature, the microstructures consist of ferrite with completely spheroidized cementite (samples S 1.1, S 2 and S 3.1), ferrite + pearlite with the residues of non-dissolved spheroidized cementite (samples S 1.2, S 3.2 and S 3.3) and pure ferrite + pearlite (samples S 3.4 and S 3.5). The presence of non-dissolved spheroidized cementite in samples S 1.2, S 3.2 and S 3.3 is a result of an insufficient duration of the heat treatment at appropriate temperatures of the strip coils with $\phi 200 / \phi 235 \mathrm{~mm}$ (18 min for heating and $18 \mathrm{~min}$ for holding). With the increasing temperature, the quantity of the non-dissolved spheroidized cementite reduces. The microstructure of sample S 3.5 consists of ferrite and lamellar pearlite. This structure is common for low-carbon steel after normalizing.

Circular blanks with a diameter of $16.5 \mathrm{~mm}$ were cut from all the strips. These blanks were radially drawn into cups with dimensions of $\phi 9.38 / \phi 6.98 \mathrm{~mm}$ and a height of approximately $10 \mathrm{~mm}$ on an industrial machine for deep drawing. These cups are used for deep drawing of bullet jackets for ammunition. Since the thickness of the strips was $1.30 \mathrm{~mm}$ and the thickness of the cup wall was $1.20 \mathrm{~mm}$, the achieved plastic deformation was $7.7 \%$. On six samples (S 1.2, S 2, S 3.1, S 3.2, S 3.3 S 3.4), four ears were formed while on two samples (S 1.1, S 3.5), ears were not formed (Figure 2). The ears were formed in the directions that were $45^{\circ}$ from the rolling direction and $45^{\circ}$ to the transverse direction. The waviness of the upper edges of the cups was measured with 3D coordinate measuring machine Carl Zeiss Contura G3 (an accuracy of $\pm 0.010 \mathrm{~mm}$ ). The results of these measurements are presented in Figure 3. Insufficiently smooth lines on this figure are results of the unevenness of the blanks' cutting surfaces.
Sample S 3.5 was deep drawn without any occurrence of ears because it was previously annealed at a temperature of $930{ }^{\circ} \mathrm{C}$. This annealing is practically a normalization with a full phase transformation and randomly oriented grains that ensure isotropic strip properties in different directions. Sample S 1.1 was also deep drawn without the occurrence of ears, unlike samples S 2 and S 3.1, although these samples have a similar thermomechanical history. The basic difference is related to the fact that sample $\mathrm{S} 1.1$ was cold rolled, subjected to a higher amount of cold deformation, i.e., $69.1 \%$ (rolling: $4.3 \mathrm{~mm} \rightarrow 2.3 \mathrm{~mm}$; annealing: $700{ }^{\circ} \mathrm{C}$; rolling: $2.3 \mathrm{~mm} \rightarrow 1.33 \mathrm{~mm}$ ), unlike samples S 2 and S 3.1 that were subjected to a cold deformation of $42.2 \%$ (rolling: $2.3 \mathrm{~mm} \rightarrow 1.33 \mathrm{~mm}$ ).

A higher amount of cold deformation in the case of sample S 1.1, including recrystallization annealing $\left(700{ }^{\circ} \mathrm{C}\right)$ reduces the negative effects of warm rolling in the alpha-gamma area on the earing process. The negative effect of heating in the alpha-gamma area on the earing can be seen on sample S 1.2 (Figure 3) that has
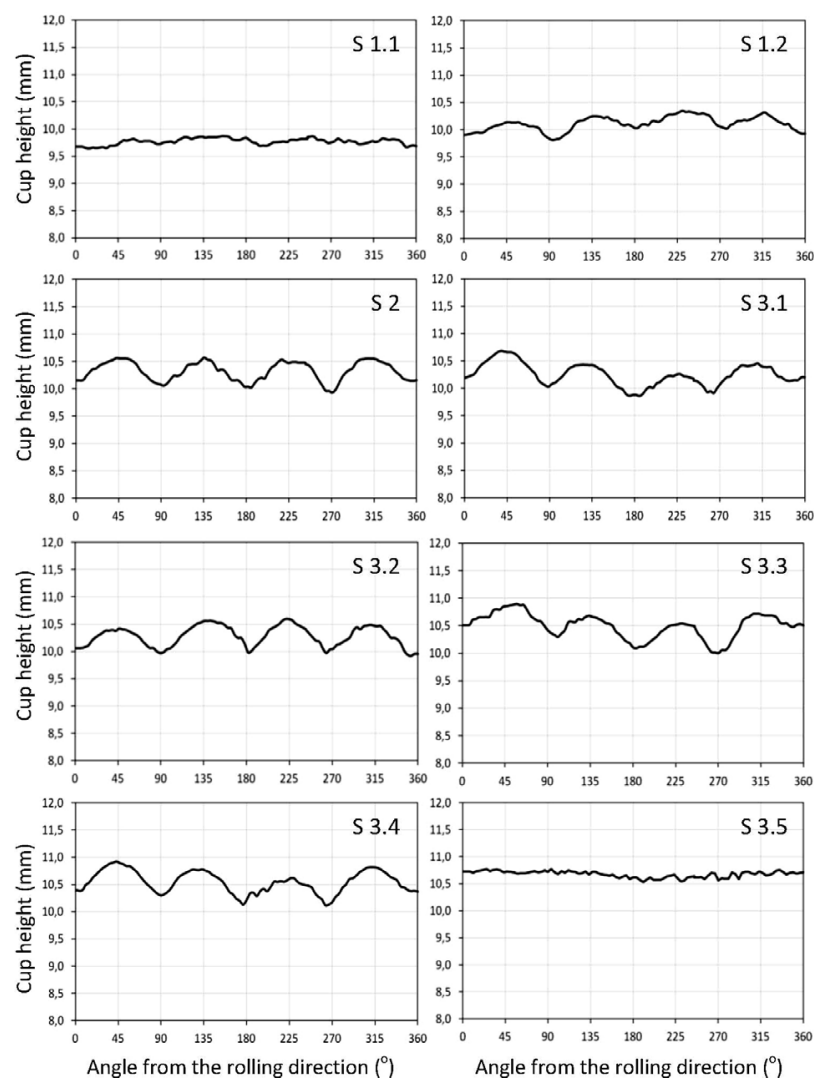

Figure 3: Variation in the cup height with the angle 
the same thermomechanical history as sample $\mathrm{S} 1.1$ but its final annealing was carried out in the alpha-gamma area $\left(800{ }^{\circ} \mathrm{C}\right)$. This negative effect in the cases of samples S 2 and S 3.1 is a result of a prolonged warm rolling of the strips in the alpha-gamma area while in the cases of strips S 3.2, S 3.3 and S 3.4, the negative effect is a result of a prolonged warm rolling of the strips in the alpha-gamma area and the final annealing in this area.

\section{CONCLUSIONS}

The earing effect in the case of cup deep drawing involving a three-layer strip can be avoided with a normalization and a higher degree of cold deformation, including intermediate recrystallization annealing. This type of normalization of strips is impractical because of a relatively high annealing temperature $\left(930^{\circ} \mathrm{C}\right)$. Intermediate recrystallization annealing performed during cold deformation is necessary to avoid the occurrence of the preferred crystallographic orientation causing anisotropy of mechanical properties. The heating of the strips in the alpha-gamma area due to annealing and warm rolling has a negative effect on earing. For this reason, annealing and prolonged warm rolling in the alphagamma area should be avoided.

\section{Acknowledgements}

The authors acknowledge the financial support of the Federal Ministry of Education and Science of the Federation of Bosnia and Herzegovina.

\section{REFERENCES}

${ }^{1}$ H. I. Demirci, Ö. Karaçali, Computer Aided Engineering (CAE) Experimental Application for Deep Drawing Processes of a Sheet Metal, 12 ${ }^{\text {th }}$ International Research/Expert Conference Trends in the Development of Machinery and Associated Technology TMT 2008, Istanbul, Turkey, 2008, 161-164

${ }^{2}$ A. Talić-Čikmiš, M. Trako, M. Karivan, Finite Element Analysis of Deep Drawing, 14 ${ }^{\text {th }}$ International Research/Expert Conference
Trends in the Development of Machinery and Associated Technology TMT 2010, Mediterranean Cruise, 2010, 81-84

${ }^{3}$ K. Shah, D. Bhatt, T. Panchal, D. Panchal, B. Dogra, Influence of the process parameters in deep drawing, International Journal of Emerging Research in Management and Technology, 3 (2014) 11, 16-22, ISSN: 2278-9359

${ }^{4}$ P. Ravikant, D. Harshit, R Harit, Study of earing defect during deep drawing process with finite element simulation, Key Engineering Materials, 639 (2015), 91-98, doi:10.4028/www.scientific.net/ KEM.639.91

${ }^{5}$ O. Saresoja, A. Kuronen, K. Nordlund, Atomistic simulation of the explosion welding process, Advanced Engineering Materials, 12 (2012) XX, 1-4, doi:10.1002/adem.201100211

${ }^{6}$ F. Findik, R. Yilmaz, T. Somyurek, The effects of heat treatment on the microstructure and microhardness of explosive welding, Scientific Research and Essays, 6 (2011) 19, 4141-4151, doi:10.5897/ SRE11.1018

${ }^{7}$ http://admin.copperalliance.eu/docs/librariesprovider5/pub-tn26the-brasses-technical-data/copper-zinc-alloys-(brasses)/cuzn10-(cw5 011)-datasheet-d2.pdf?sfvrsn, 26.05.2018

${ }^{8}$ http://www.mueller-hespert.de/images/uploads/emhPDF/Datasheet_CuZn10.pdf, 26.05.2018

${ }^{9}$ O. Beganović, B. Fakić, A. M. A. Mohammedzain, A. O. M. Babekir, F. Uzunović, Effect of Deformation and Heat Treatment on Microstructure of Warm Rolled Steel in Alpha-Gamma Area, $12^{\text {th }}$ Scientific/Research Symposium with International Participation "Metallic and Nonmetallic Materials" B\&H, 2018

${ }^{10}$ M. Umemoto, Y. Todaka, K. Tsuchiya, Mechanical properties of cementite and fabrication of artificial pearlite, Materials Science Forum, 426-432 (2003), 859-864

${ }^{11}$ H. S. Valberg, Applied Metal Forming Including FEM Analysis, Cambridge University Press, 2010, 3

${ }^{12}$ R. Song, D. Ponge, D. Raabe, R. Kaspar, Microstructure and crystallographic texture of an ultrafine grained C-Mn steel and their evolution during warm deformation and annealing, Acta Materialia, 53 (2005), 845-858, doi:10.1016/j.actamat.2004.10.051

${ }^{13}$ B. L. Bramfitt, Structure/Property Relationships in Irons and Steels, Metals Handbook Desk Edition, $2^{\text {nd }}$ ed., J. R. Davis, Editor, ASM International, 1998, 153-173

${ }^{14}$ Kumkum Banerjee: Physical Metallurgy and Drawability of Extra Deep Drawing and Interstitial Free Steels, IntechOpen, doi:10.5772/ 35073, March $7^{\text {th }} 2012$, Available from: https://www.intechopen. com/books/recrystallization/physical-metallurgy-and-drawability-ofextra-deep-drawing-and-interstitial-free-steels, 15.06.2018

${ }^{15}$ O. Beganović, A. Čamdžić, F. Uzunović, Effect of Uneven Plastic Deformation on Width of Clad Layers of Explosive Welded ThreeLayer Strip, $12^{\text {th }}$ Scientific/Research Symposium with International Participation "Metallic and Nonmetallic Materials" B\&H, 2018 